\title{
Indian black rice: a brewing raw material with novel functionality
}

Kamaljit Moirangthem ${ }^{\mathrm{a}}$, David Jenkins ${ }^{\mathrm{b}}$, Priya Ramakrishnac,\#, Ranjana Rajkumarid and David $\mathrm{Cook}^{\mathrm{b*}}$

a Division of Nutritional Sciences: The University of Nottingham; Sutton Bonington Campus, Loughborough, Leicestershire. LE12 5RD, UK.

b International Centre for Brewing Science. Division of Microbiology, Brewing \& Biotechnology, The University of Nottingham, Sutton Bonington Campus, Loughborough, Leicestershire. LE12 5RD, UK.

c Division of Plant and Crop Sciences: The University of Nottingham; Sutton Bonington Campus, Loughborough, Leicestershire. LE12 5RD, UK.

${ }^{d}$ Department of Botany: Dhanamanjuri University, Imphal, Manipur, 795001, India

*Corresponding author:

E-mail: david.cook@nottingham.ac.uk

Tel: +44 (0)1159516245

\# Current address: Department of Botany and Plant Biology, University of Geneva, Geneva 1211, Switzerland 
1 ABSTRACT (250 words current 295)

2 Indian black rice (Chakhao Poireiton) is a pigmented variety, rich in anthocyanins and other 3 phytonutrients. With increasing interest in the use of local raw materials in brewing, it was of 4 interest to develop protocols for malting and brewing with Chakhao Poireiton to see in 5 particular whether the antioxidant capacity of anthocyanins could be delivered into finished 6 beer. Protocols for brewing with 100\% malted rice were developed and the performance of 7 Indian black rice compared with that of an Italian white rice cultivar suited to brewing. The 8 apparent fermentabilities of rice worts were $69.5 \%$ (black) and $67.3 \%$ (white), yielding beers 9 of 3.28 and $3.19 \%$ ABV respectively. Black rice worts were FAN deficient $(83.5 \mathrm{mg} / \mathrm{L}$ relative 10 to $137 \mathrm{mg} / \mathrm{L}$ for white rice) and would need nitrogen supplementation to avoid issues with 11 fermentation, e.g. elevated diacetyl. Black rice beer had an orange-red hue as a result of 12 extraction of anthocyanin pigments $(2.84 \mathrm{mg} / \mathrm{L})$. The oxidative stability of $100 \%$ rice beers 13 was measured using Electron Spin Resonance (ESR) spectroscopy and both samples were 14 found to be unusually stable. Interestingly, when rice beers were blended with a control 15 barley malt derived lager in varying proportions $(10,25,50 \%)$, the oxidative stability was 16 improved, relative to the control lager, particularly so in the case of black rice beer, which 17 contained an antioxidant capacity over and above that of the white rice beer. Future studies 18 are required to determine whether the noted oxidative stability of $100 \%$ rice malt beers 19 results in a more flavour stable beer.

21 KEYWORDS: Indian black rice, 100\% rice beer, ESR, beer oxidative stability, beer 22 polyphenols. 


\section{INTRODUCTION}

India is the largest rice producer in the world. With around $80 \%$ of this production utilized for domestic consumption, it is also the largest consumer of rice ${ }^{1}$. The North - Eastern states of India, such as Manipur, are home to a diverse range of traditional aromatic rice landraces ${ }^{2}$. Once such variety, very popular in Manipur is the black rice - Chakhao Poireiton, belonging to the species Oryza sativa L. indica.

Black rice appears black due to the presence anthocyanins, dark purple pigments, which are present in its bran layer. Anthocyanins are antioxidants and the levels accumulated in black rice bran are considered to be one of the highest levels found in foods ${ }^{3}$. Anthocyanins are known for their ability to protect cells from damage due to biotic and abiotic stresses and have also been considered as potential cancer chemo-preventative agents ${ }^{4}$. As a dietary antioxidant, they can also help combat reactive oxygen species, free radicals and help decrease the risk of chronic diseases such as coronary heart disease ${ }^{5}$. Additionally, they are approved for use as a food additive or colouring agent in the EU, Australia and New Zealand with the E number E163 (INS number 163) ${ }^{6}$.

In addition to antioxidants, black rice contains high amounts of flavonoid phytonutrients, gamma oryzanol, polyphenols, Vitamin E, dietary fibre and minerals such as iron and copper. It is a better source of plant based protein than normal white rice ${ }^{7}$. It is thus considered to be a premium rice product from a nutritional perspective. There have been very limited studies on black rice Chakhao Poireiton. It is a waxy rice and has been reported to be composed of approximately $7 \%$ protein, $4 \%$ fat, $76 \%$ carbohydrate and $2 \%$ amylose with a gelatinisation temperature between 75 and $92^{\circ} \mathrm{C}^{8}$. Figure 1 shows the paddy and different fractions of black rice as it goes through an industrial milling process. However, black rice is usually not polished in order to maintain its bran and the anthocyanin, giving the rice a chewy texture when cooked.

In the brewing industry rice has been used as an adjunct mainly due to its neutral flavour. However, brewing a $100 \%$ rice beer is somewhat more challenging. Its starch fails to undergo complete saccharification during mashing. This has been reported to be attributed to the high gelatinization temperature of its starch, insufficient starch-degrading enzymes in malted rice and insufficient degradation of the structural protein of the endosperm cell wall needed prior to or simultaneously with starch modification ${ }^{9}$. There have been only limited studies on the production of rice beer. Usansa et al. reported that enzyme production during malting of rice was dependent on the rice variety and did not correlate with amylose content ${ }^{10}$. There have been reports of successful brewing with $100 \%$ rice malt, made possible by optimising the mashing conditions ${ }^{9}$, and of the experimental development of speciality rice malts, roasted to enhance flavour and the colour ${ }^{11}$. Amylase activity, needed for starch degradation, depends greatly on the different incubation conditions. For rice, the minimum temperature is $10-12{ }^{\circ} \mathrm{C}$, the optimal temperature is $30-37^{\circ} \mathrm{C}$ and the maximum temperature is $40-42{ }^{\circ} \mathrm{C}$ inside ${ }^{12}$. Additionally, optimum temperature conditions for malting black rice were reported to be $30{ }^{\circ} \mathrm{C}^{13,14}$, which is close to room temperature in Asian countries. Ceppi and Brenna, reported development of a gluten-free beer (3.5-4.5\% ABV) using Italian rice variety Loto and a mashing-in liquor to grist ratio of 1:3.5 ${ }^{15}$. Mayer et al, likewise reported an all rice gluten free beer (4.4-4.8\% ABV) produced with Italian rice variety Centauro and a mashing-in liquor to grist ratio of $1: 4^{9}$. 
70 Black rice forms an important part in the Manipuri culture and in ceremonies to prepare 71 various unique dishes. However, the cultivation of Chakhao landraces is declining, as it cannot 72 compete with modern high yielding non-coloured varieties ${ }^{2}$. There has been no published 73 work on black rice Chakhao Poireiton beer. This research aimed to investigate the use of this 74 Indian black scented rice in the brewing process with a view to improving its commercial 75 value. Finding additional uses of this unique native commodity in the brewing Industry could 76 be of interest to the growing Indian brewing Industry. It could ultimately warrant its 77 agronomical improvement to develop higher yielding varieties and revitalise its cultivation. 


\section{MATERIALS AND METHODS}

\section{Raw materials}

Paddy black rice of the variety Chakhao poireiton, was imported from Imphal, India. For comparison, paddy white rice of the variety Centauro was imported from Pavia, Italy. Both samples of rice were harvested in 2016.

83

\section{Malting}

Malting of the rice varieties was conducted in biological duplicate as paddy rice in an automatic micromalting system (Curio Malting, Milton Keynes, UK). Steeping and germination was conducted at $30^{\circ} \mathrm{C}$ in batches of $3.2 \mathrm{~kg}$ ( $400 \mathrm{~g} \mathrm{X} 8$ cages) for 72.7 hours according to the protocol shown in Table 1 . Steep water was renewed for each wet cycle and turning of the malting cages maintained at $1 \mathrm{~min}$ in every $10 \mathrm{~min}$ throughout the process. Kilning of rice malts used the following cycle: $45^{\circ} \mathrm{C} \times 12 \mathrm{~h} \rightarrow 50^{\circ} \mathrm{C} \times 12 \mathrm{~h} \rightarrow 55^{\circ} \mathrm{C} \times 13.5 \mathrm{~h} \rightarrow 70^{\circ} \mathrm{C} \times 6 \mathrm{~h} \rightarrow 1 \mathrm{~h}$ cooling. Kilned malts were hand deculmed to remove the coleoptile and primary roots. Finished malts were packaged under vacuum into sealed foil-laminated pouches using a vacuum sealer (Audionvac VMS 43).

\section{Brewing of rice beers}

\section{Wort preparation}

Infusion mashing was conducted in a Braumeister one vessel professional brewing system, ( 25 L scale; Braumeister, Speidel, Germany) by adapting the process described by Mayer et $\mathrm{al}^{9}$. Rice malt ( $3 \mathrm{~kg}$ ) was milled using a Bühler Miag Disc mill (Bühler, Braunschweig, Germany) with a gap setting of $0.5 \mathrm{~mm}$. The milled grist was added to $22 \mathrm{~L}$ of brewing water at $45^{\circ} \mathrm{C}$. The mixture was supplemented with $3.75 \mathrm{~g}$ of $\mathrm{CaCl}_{2} .2 \mathrm{H}_{2} \mathrm{O}$ and mash $\mathrm{pH}$ was quickly adjusted to 5.05 using lactic acid. Mashing was conducted by increasing the temperature at a ramp rate of $1^{\circ} \mathrm{C} / \mathrm{min}$ in between the following temperature stands: $30 \mathrm{~min}$ at $45^{\circ} \mathrm{C}, 45 \mathrm{~min}$ at $65^{\circ} \mathrm{C}, 60$ min at $74^{\circ} \mathrm{C}$, and $60 \mathrm{~min}$ at $78^{\circ} \mathrm{C}$ giving a total mashing time of $228 \mathrm{~min}$ (Figure 2). lodine tests for starch showed negative towards the end of the $78^{\circ} \mathrm{C}$ stand. Lautering was conducted for $30 \mathrm{~min}$ with $1 \mathrm{~L}$ of sparge water at $80^{\circ} \mathrm{C}$. Mash was subsequently boiled for $1 \mathrm{~h}$ with the addition of 5 grams of hops (Zeus T90 pellet hops with specified $15-17 \% \alpha$-acid content) and the wort cooled to $20^{\circ} \mathrm{C}$ prior to pitching.

\section{Fermentation and maturation}

The cooled clarified wort was transferred to a $30 \mathrm{~L}$ conical fermenter (FastFerment ${ }^{\mathrm{TM}}$, Ontario, Cannada) and pitched with $11 \mathrm{~g}$ of Nottingham ale yeast (Danstar; Lallemand Inc., Montreal, Canada). Fermentation temperature was maintained at $20^{\circ} \mathrm{C}$ for 4 days. Following this the vessel was cooled and stored at $4^{\circ} \mathrm{C}$ for 6 days to permit the settling out of yeast and precipitate particles. The yeast was cropped from the bottom of the tank. The unfiltered beer was bottled, primed with $3 \mathrm{~g}$ of dextrose and matured for 21 days at $20^{\circ} \mathrm{C}$.

\section{Wort analysis}

The following parameters were measured in duplicate:

pH-using hand held $\mathrm{pH}$ meter (EzDo 7011). Specific gravity - using a hand-held density meter (DMA 35, Anton Paar, Graz, Austria). Colour - measured at $430 \mathrm{~nm}$ according to EBC 4.7.1 and also using a Hunterlab tristimulus colour measurement system (ColorQuest XE, Hunterlab, Germany). Free Amino Nitrogen (mg/L) - using the ninhydrin spectrophotometric method 
according to EBC 8.10. Total polyphenols (mg/L) - according to the International method

124 (ASBC Beer-35).

125 Concentrations of individual phenolic compounds were analysed by HPLC according to the method described by Oladokun et $a^{16}$. Briefly, ethyl acetate extracts were evaporated to dryness, reconstituted in methanol and separated using a Waters Alliance 2695 HPLC fitted with a Purospher STAR rp-18 end-capped column $(250 \times 4.6 \mathrm{~mm}, 3 \mu \mathrm{m}$ particle size; Merck Millipore, UK) coupled with a C18 guard cartridge from Phenomenex (UK). Peak areas were extracted at $280 \mathrm{~nm}$ and total run time was $65 \mathrm{~min}$. Samples were analysed in triplicate and phenolic acid concentrations were determined from calibration curves generated from external standards run at concentrations of $1,10,20,40 \mathrm{mg} / \mathrm{L}$.

Beer analysis: The following parameters were measured in duplicate as for wort above: $\mathrm{pH}$, specific gravity, colour, Free Amino Nitrogen, total polyphenols, phenolic compounds by HPLC. In addition, alcohol (\% ABV) was measured using an Anton Paar Alcolyzer Plus (Anton Paar, Graz, Austria). Foam stability of the beer (30 mm foam collapse time - FCT30) was measured using a Nibem-TPH Foam Stability meter (Haffmans, The Netherlands) according to EBC 9.42.

\section{Measurement of the total anthocyanin content of beers}

The total anthocyanin content (TAC) was determined using the $\mathrm{pH}$-differential method 17. The TAC was calculated using equation (1) and expressed as milligrams of cyanidin 3glucoside (cyn 3-glu) equivalents/mL of solution:

$$
\operatorname{TAC}(\mathrm{mg} / \mathrm{mL})=\frac{\mathrm{A} \times \mathrm{MW} \times \mathrm{DF} \times 1000}{\varepsilon}
$$

Where, $A=\left(\mathrm{A}_{510}-\mathrm{A}_{700}\right)_{\mathrm{pH} 1.0}-\left(\mathrm{A}_{510}-\mathrm{A}_{700}\right)_{\mathrm{pH}} 4.5 ; M W$ is the molecular weight of anthocyanin $(449.2 \mathrm{~g} / \mathrm{mol}), D F$ is the dilution factor and $\varepsilon$ is molar absorbance of cyn $3-\mathrm{glu}(26,900$ $\mathrm{L} / \mathrm{mol} / \mathrm{cm})$.

\section{Measurement of the oxidative stability of rice beers using Electron Spin Resonance (ESR) spectroscopy.}

The oxidative stability of beers were assayed using a forcing test at $60{ }^{\circ} \mathrm{C}$ during which the time-course of free radical formation was measured using Electron Spin Resonance spectroscopy (Bruker E-scan; Bruker Corporation, MA, USA) with N-tert-Butyl- $\alpha$ phenylnitrone (PBN) as spin trap ${ }^{18}$. PBN (678 mg) was dissolved first in $500 \mu \mathrm{L}$ of ethanol (Fisher Scientific) and $500 \mu \mathrm{L}$ water added. 280uL of PBN solution was added to each beer sample $(7 \mathrm{~mL})$. Samples were placed in a $60{ }^{\circ} \mathrm{C}$ heating block at 60 second intervals. ESR spectra were recorded with a centre field of $3478 \mathrm{G}$ and sweep width of $17 \mathrm{G}$. The microwave bridge had a power of $2.31 \mathrm{~mW}$ and frequency of 9.77. Receiver gain was 1261, modulation frequency $86 \mathrm{kHz}$, modulation amplitude $1.1 \mathrm{G}$, modulation phase $0.85^{\circ}$, time constant 20.48 ms. Scans were aggregated and the peak to peak height of the first derivative of the EPR spectra was recorded as the intensity value at a given time point. Samples were taken at approximately $10 \mathrm{~min}$ intervals across the assay time using an autosampler (Bruker Corporation, MA, USA) and the running order was randomised. 

chromatography (GC-HS-FID)

170 Volatile analysis was conducted using a modified version of EBC Method 9.39. Beer samples were chilled to $4^{\circ} \mathrm{C}$ and sonicated for about 10 seconds. Degassed beer sample $(10 \mathrm{~mL})$ was transferred to a headspace vial, $50 \mu \mathrm{l}$ of internal standard (10,000 ppm 1-butanol) added, followed by $3.5 \mathrm{~g}$ of sodium chloride and the vial was quickly sealed tight using a crimper.

Analysis was conducted by HS-GC-FID (SCION 456-GC, Bruker Corporation, MA, USA) fitted with ZB-Wax column ( $60 \mathrm{~m} \times 0.25 \mathrm{~mm}$ i.d., $0.50 \mu \mathrm{m}$ film thickness), under a constant $15 \mathrm{psi}$ pressure with helium as carrier gas. Injection volume was $500 \mu \mathrm{L}$ at a split ratio of 1:20. Run time was $36.25 \mathrm{~min}$ with an additional $20 \mathrm{~min}$ agitation time. The GC oven was programmed for an initial $85^{\circ} \mathrm{C}$ for $10 \mathrm{~min}, 110^{\circ} \mathrm{C}$ for $13 \mathrm{~min}$ (ramp @ $25^{\circ} \mathrm{C} / \mathrm{min}$ ), $200^{\circ} \mathrm{C}$ for $13.25 \mathrm{~min}$ (ramp $@ 8^{\circ} \mathrm{C} / \mathrm{min}$ ). The temperatures of the injection port and FID detector were $150^{\circ} \mathrm{C}$ and $250^{\circ} \mathrm{C}$, respectively.

\section{Vicinal diketone (VDK) analysis by Head Space Gas Chromatography (GC-HS-} ECD)

VDK analysis was conducted using a method based on EBC 9.42.2 which can detect and quantify diacetyl (0-0.25 ppm) and 2,3-pentanedione (0-0.25 ppm) using 2,3-hexanedione as an internal standard. Samples were chilled to $4^{\circ} \mathrm{C}$, degassed in a cooled shaking incubator at $175 \mathrm{rpm}$ for $5 \mathrm{~min}$ and filtered through a $0.45 \mu \mathrm{m}$ syringe filter. Beer samples $(5 \mathrm{~mL})$ were transferred to individual headspace vials, $50 \mu$ of internal standard ( $5 \mathrm{ppm}$ ) added, followed by $3.5 \mathrm{~g}$ of ammonium sulphate and the vial was quickly sealed tight using a crimper. Analysis was conducted by HS-GC-ECD using a SCION 456-GC (Bruker Corporation, MA, USA) fitted with a Restek Rtx-5MS ( $30 \mathrm{~m} \times 0.25 \mathrm{~mm}$ id $\times 0.25 \mu \mathrm{m} \mathrm{df}$ ) column, under a constant $50 \mathrm{psi}$ pressure and with helium as carrier gas. Injection volume was $500 \mu \mathrm{L}$ at a split ratio of 1:5. Run cycle time was $12 \mathrm{~min}$ with an additional $20 \mathrm{~min}$ agitation time. The GC oven profile started with an initial hold at $30^{\circ} \mathrm{C}$ for $2 \mathrm{~min}$ followed with a linear ramp to a final temperature of $120^{\circ} \mathrm{C}$ which was held for $2 \mathrm{~min}\left(\mathrm{ramp}\right.$ at $\left.70^{\circ} \mathrm{C} / \mathrm{min}\right)$. The temperatures of the injection port and $\mathrm{ECD}$ detector were $110^{\circ} \mathrm{C}$ and $150^{\circ} \mathrm{C}$, respectively.

\section{Elemental analysis of rice beers using Inductively Coupled Plasma Mass} Spectrometry (ICP-MS)

Beer samples were degassed by sonication ( $5 \mathrm{~min}$ ). All samples were diluted (1:10) with nitric acid $(2 \%)$ by pipetting the sample $(1 \mathrm{~mL})$ and nitric acid $(2 \%, 9 \mathrm{~mL})$ into a $10 \mathrm{~mL}$ plastic sample tube. Sample tubes were capped and inverted three times. Diluted samples were stored at $2^{\circ} \mathrm{C}$ pending elemental analysis.

A multi-element analysis of diluted beer sample was undertaken by ICP-MS (Thermo-Fisher Scientific X-SeriesII) with a 'hexapole collision cell' (7\% hydrogen in helium) to remove polyatomic interferences. Samples were introduced from an autosampler (Cetac ASX-520 with 4 × 60-place sample racks) through a concentric glass venturi nebuliser (Thermo-Fisher Scientific; $1 \mathrm{~mL} / \mathrm{min}$ ). Internal standards were introduced to the sample stream via a ' $T$ '-piece and included Sc $(100 \mathrm{ng} / \mathrm{mL}), \mathrm{Rh}(20 \mathrm{ng} / \mathrm{mL})$ and $\operatorname{Ir}(10 \mathrm{ng} / \mathrm{mL})$ in $2 \%$ nitric acid. External multielement calibration standards (Claritas-PPT grade CLMS-2, Certiprep/Fisher) included Fe, $\mathrm{Cu}$ and $\mathrm{Mn}$ in the range $0-100 \mu \mathrm{g} / \mathrm{L}$. Sample processing was undertaken using Plasmalab software 
213 (version 2.5.4; Thermo-Fisher Scientific) set to employ separate calibration blocks and internal 214 cross-calibration where required. 


\section{RESULTS AND DISCUSSION}

216 Paddy rice samples were germinated at $30^{\circ} \mathrm{C}$, kilned at $70^{\circ} \mathrm{C}$ and hand deculmed. Both varieties of rice germinated at a similar rate and after two days distinct coleoptiles were visible (Figure 3). Total malting time was reduced from the 8 days ${ }^{19}$ used in a prior study, to just 3 days. This short malting time was achieved at a higher germination temperature of $30^{\circ} \mathrm{C}$, and would most likely result in lower malting losses (in roots and coleoptile). Under similar conditions: steeping for 24 hours and germinating at $30^{\circ} \mathrm{C}$, six white Thai rice cultivars have been reported to result it average malting losses of $10 \%, 20 \%$ and $40 \%$ for a total malting time of 4,5 and 6 days respectively ${ }^{10}$.

Rice malts were mashed using the schedule shown in Figure 2. Lautering proceeded without difficulty, probably due to the low gravity of the worts (ca. $\left.9^{\circ} \mathrm{P}\right)$ and to the rice husk forming an efficient filter bed. For both the rice varieties, fermentation of the wort resulted in a similar decrease in $\mathrm{pH}$, and specific gravity (Figure 4). This suggests that the two varieties of rice produced worts of similar quality which had comparable fermentabilities (69.5 and $67.3 \%$ for black and white rice worts respectively; Table 2) generating final ethanol contents in the region of $3.2 \% A B V$.

232

The rice grist ( $3 \mathrm{~kg}$ ) yielded $1.29 \pm 0.02$ and $1.19 \pm 0.06 \mathrm{~kg}$ of oven dried spent grains for black and white rice malts respectively. This equated to an extract rate of approximately $60 \%$ by weight for each malt. Rice husk comprises $\sim 20 \%$ of paddy rice ${ }^{20}$. Although, this is higher than for traditional brewing feedstocks such as barley $\left(10 \%{ }^{21}\right)$, the husk has been reported to assist in an efficient lautering process ${ }^{19}$. However, rice husk is tougher than barley husk and of the two rice varieties used, black rice has a tougher husk than the white rice husk. This could create challenges in scaling up this process, especially when pumping the mash. Careful milling would be required in order to balance husk preservation (to aid lautering) against potential impacts on the physical properties of the mash.

The average Free Amino Nitrogen (FAN) contents of rice worts were 83.5 and $137 \mathrm{mg} / \mathrm{l}$ for black and white rice respectively (Table 2). Protein contents of the two rice varieties have been previously reported to be $6.6-7.7 \%$ for Chakhao Poireiton ${ }^{8,22}$ and $7.6-8.8 \%$ for Centauro $^{19}$. In addition to having a higher FAN content, the white rice FAN was more completely assimilated by the yeast, with $89 \%$ consumption across fermentation compared to $66 \%$ of FAN utilisation for the black rice beer (Table 2). However, this apparently did not impact on alcohol production. The FAN content of all rice malt wort $\left(12^{\circ} \mathrm{P}\right)$ was previously reported to range between $160-179 \mathrm{mg} / \mathrm{L}^{9}$. It can be concluded that, despite the relatively low wort FAN level in the present experiments, there was sufficient yeast growth to ferment the wort and produce alcohol. It is likely that any brewing process based on $100 \%$ black rice malt would require nitrogen-supplementation for optimal yeast health and fermentation progression, particularly when brewing at higher gravities where higher wort FAN levels are required ${ }^{23}$.

Rice beers poured with a generous, coarse white foam and were visually somewhat hazy (Figure 5), with the white rice beer being substantially more turbid. The reasons for the different turbidities in finished beer is not clear based on present data, however, one possibility is that the elevated polyphenol content of black rice aided the precipitation of haze active protein from the black rice beer either in the brewhouse or through 
fermentation/maturation. It is likewise possible that the difference results from different protein or starch solubilisation during processing of the 2 different varieties. The most striking difference between the two beers was in terms of colour (Figure 5, Table 2). Black rice beer had a pink-orange hue (elevated a* colour co-ordinate; Table 2) whereas the white rice beer had a more conventional golden lager hue. Usually in brewing the wort/beer colour increases at higher $\mathrm{pH}$ values as the extent of colour pick-up via the Maillard reaction is greater at a higher wort $\mathrm{pH}$ values. However, with black rice wort and beer the colour is primarily imparted by anthocyanins, whereby $\mathrm{pH}$ directly impacts the colours of the pigments - tending towards red hues at the low beer $\mathrm{pH}$ values resulting for black rice beer ( $\mathrm{pH}$ 3.6). It can also be noted that the buffering capacity of both rice beers was lower than is encountered for barley malt brewed beers, where a final $\mathrm{pH}$ of around 4.0-4.2 is typical. This could relate to the very low residual FAN content in both rice beers.

274

\section{Phenolic content of rice beers}

Anthocyanins were only detected in the black rice wort and beer (Table 2). The anthocyanin content of de-husked powdered Chakhao Poireiton has been reported to be around 740 $\mathrm{mg} / \mathrm{kg}^{4}$. Taking the percentage of husk in paddy rice to be approximately $20 \%{ }^{20}$ suggests an actual anthocyanin content in the region of $\sim 600 \mathrm{mg} / \mathrm{kg}$. Anthocyanin content of black rice wort was $4.9 \pm 1.7 \mathrm{mg} / \mathrm{l}$ (Table 2 ) and was further reduced during fermentation to $2.8 \pm 1.1 \mathrm{mg} / \mathrm{l}$ (Table 2). The apparently low transfer rate of anthocyanins into wort is most likely due to their heat labile nature. Much of the anthocyanin is believed to have degraded during the mashing process at temperatures up to $78{ }^{\circ} \mathrm{C}$. Cyanidin-3-glucoside is one of the major anthocyanins present in Poireitin ${ }^{4}$. The cyanidin-3-glucoside content of black rice (Oryza sativa L. japonica var. SBR) has been reported to decrease by up to $80 \%$ during cooking ${ }^{24}$ (e.g. for $20 \mathrm{~min}$ in a pressure cooker). Chakhao Poireiton has been reported to have anthocyanins which are more heat stable compared to other black rice varieties ${ }^{22}$. Hence, use of other black rice varieties under similar processing conditions could result in almost total loss of anthocyanins.

A decrease in TPC was observed between wort and finished rice beers (Table 3). This could reflect losses through adsorption to yeast cells or through chill haze formation and removal. For both the wort and beer samples, brewing with black rice resulted in a 4-fold greater TPC than with white rice (Table 3). In lager beers the typical TPC is in the range of $150-340 \mathrm{mg} / \mathrm{l}^{25}$. HPLC analysis indicated that both rice beers contained a broad range of phenolic compounds Table 3). It was notable that protocatechuic acid was only detected in black rice worts. This compound could be associated with the degradation of cyanidin-3-glucoside (or related anthocyanins) as has previously been reported during cooking of black rice (Oryza sativa $\mathrm{L}$. japonica var. SBR) ${ }^{24}$. Tyrosol and indole-3-acetic acid were only detected in rice beers and not in the respective worts, indicating that they were formed or imparted to the beer through fermentation. There was a corresponding increase in the sum of individual phenolic acid contents after fermentation: 12.06 to $25.6 \mathrm{mg} / \mathrm{l}$ (black rice wort to beer) and 2.62 to 30.25 $\mathrm{mg} / \mathrm{l}$ (white rice wort to beer). Tyrosol is an antioxidant and the Ehrlich pathway degradation product of the amino acid tyrosine. Hence the greater amounts noted in white rice beers (Table 3) likely corresponds with the noted higher wort FAN content (Table 2). 
310 Fermentation volatiles were analysed by gas chromatography using a headspace injection technique (Table 4). Concentrations of volatile esters such as ethyl acetate, ethyl hexanoate and isoamyl acetate, in the rice beers were comparable with, but towards the lower end of the ranges typically reported for barley malt beers (Table 4). VDK analysis indicated that the black rice beer contained diacetyl $(0.34 \mathrm{mg} / \mathrm{L}$; Table 4$)$ in excess of its flavour threshold (0.1$0.15 \mathrm{mg} / \mathrm{L}$ ). This would be regarded as a flavour defect in conventional lager beers and was most likely caused here by the noted low FAN values in black rice wort (Table 2). VDKs are released into the fermenting wort and are subsequently assimilated by yeast towards the end of fermentation ${ }^{26}$. Diacetyl is formed as an off-shoot of the pathway for valine synthesis in yeast and the higher values observed in black rice worts and beer (Figure 7 and Table 4) reflect: i) increased activity through the valine synthesis pathway and ii) slower uptake and assimilation of diacetyl by the reduced cell mass of yeast resulting from the low wort FAN content (although this did not materially impact on fermentation progression relative to the white rice beer fermentations). At low concentrations diacetyl provides a butterscotch-like aroma whereas pentanedione is detected as honey-like ${ }^{27}$. Of the two main VDK in beer, diacetyl is generally present in concentrations that are approximately 10 times higher than those for 2,3-pentanedione ${ }^{28}$. The latter was also true of the beers in this study.

Beer foam is one of the important visual attributes by which consumers judge beer quality ${ }^{29}$. This characteristic is influenced by both the raw materials used and the brewing process. Black rice beers $(257 \pm 23.8 \mathrm{sec})$ had a significantly higher Nibem foam stability (FCT30) than white rice beers $(209 \pm 15.7 \mathrm{sec})$ in this study.

Although detailed sensory characterization of the $100 \%$ rice beers was beyond the scope of the present study, the beers were tasted by experienced brewers within our team. VDK character was picked up, particularly on the black rice beers. As discussed above this could readily be addressed by nitrogen supplementation of the wort prior to fermentation. Furthermore, rice beers had their own individual characteristics, being slightly sour (due to the lower beer $\mathrm{pH}$ ) and with an aroma note present which was reminiscent of cooked rice pudding.

\section{Oxidative stability of rice beers}

Lag time values determined using the ESR forced ageing method indicate the endogenous anti-oxidative potential of a beer and are directly related to its oxidative stability. Furthermore, the T150 value (signal after $150 \mathrm{~min}$ of the assay with PBN spin trap) is commonly cited as a comparative index of the extent of radical formation after a fixed time of forcing. It was immediately notable that both rice beers were unusually stable in terms of their ESR forced ageing responses (Figures 6A and 6B). The traditional inflection in signal intensity associated with exhaustion of the antioxidant capacity was very hard to discern for $100 \%$ rice beers as the ESR signals generated were relatively flat with only a gradual increase in signal intensity over $150 \mathrm{~min}$ at $60^{\circ} \mathrm{C}$. The ESR traces observed for black and white rice beers were very similar to one another both in the freshly fermented and matured beers. A typical ESR lag-time curve for a barley malt-derived commercial lager beer, which was run under the same conditions as a part of the same experiment, is plotted (orange curve) on Figures 6A

354 and $6 \mathrm{~B}$ by way of comparison. The question arises - were the $100 \%$ rice beers highly oxidatively stable because they contained a relatively powerful array of antioxidants, or 
because they lacked pro-oxidant species which are normally present in barley malt beers? We decided to investigate this further by performing ESR forcing tests on samples generated by blending proportions of each rice beer $(25,50 \%)$ into the commercial lager beer (Figure $6 C$, black rice; Figure 6D, white rice). Interestingly, the blending of black rice and commercial lager beers resulted in the expected reductions in T150 values, in proportions that approximately corresponded with the blend ratio and the T150's of the individual samples (Figure 6C). At $50: 50$ the commercial lager/ black rice mix had a T150 value $(48,600)$ that was around $53 \%$ of that of the commercial lager beer $(90,400)$. However, with the white rice beer, incorporation at $25 \%$ made no difference to the measured T150 relative to the commercial lager beer and even in a $50: 50$ blend ratio the T150 value $(72,900)$ was as much as $81 \%$ of that in the commercial lager alone. Based on these results it is speculated that $100 \%$ rice beers lack significant pro-oxidant species which are present in malt derived lager beers and also that they contain antioxidant species which can enhance the antioxidant capacity of beers. Furthermore, it can be concluded that the black rice beers contained species which improved the oxidative stability of the commercial lager beer when the two were mixed in blends and that this trend was more evident when blending in the black rice beer as opposed to the white rice beer (comparing Figures 6 C \& D).

373

Elemental analysis of rice beers using Inductively Coupled Plasma Mass Spectrometry (ICP-MS)

Thirty-one metallic elements, including almost all essential and toxic metals such as lead, cadmium, mercury, arsenic, silver, and thallium, were quantified in both of the beers by ICPMS (Table 5). For comparative purposes a 'control lager' beer brewed from $100 \%$ barley malt was submitted for analysis alongside the rice beers to highlight major differences in elemental composition relative to the primary grist materials used.

Rice beers were relatively rich in magnesium and contained less potassium than the control lager. When considering the oxidative stability of beers there is much focus on the concentrations of transition metals such as iron, copper and manganese, which can catalyse the formation of pro-oxidant radical oxygen species ${ }^{18}$. In view of the noted oxidative stability of $100 \%$ rice beers it is interesting to note that they contained very low levels of iron and copper relative to the control lager (Table 5). However, the converse was true of manganese which was present at $\mathrm{mg} / \mathrm{L}$ quantities, more than 10-fold higher than in the control lager $(177.8 \mu \mathrm{g} / \mathrm{L})$. Apparently this did not damage the oxidative stability of the $100 \%$ rice beers, perhaps due to the form in which manganese is present when brewing with $100 \%$ rice. This may favour the extraction of manganese through the brewing process, since reports elsewhere in the scientific literature of typical manganese contents of the raw materials themselves do not suggest such a high discrepancy as was noted here in the finished beers (raw rice $21 \mathrm{mg} / \mathrm{kg}$ dry weight, raw wheat $31 \mathrm{mg} / \mathrm{kg}$ and raw barley $29 \mathrm{mg} / \mathrm{kg}^{30,31}$ ).

Arsenic concentrations in rice beers $(14.86 \mu \mathrm{g} / \mathrm{l}$ and $27.9 \mu \mathrm{g} / \mathrm{l}$ for black and white rice beer respectively) are of particular interest due to concerns about arsenic contents in rice. These results will reflect differences in the mineral contents due to the soil of the cultivation areas (India vs Italy) and also the cultivars (black vs white). Arsenic content of Italian beers has been reported to be 3-24 $\mu \mathrm{g} / \mathrm{l}^{32}$, Polish beer ranged from 2-13 $\mu \mathrm{g} / \mathrm{l}^{33}$ and for beers bought in New York ranged from 0.33 to $21.32 \mu \mathrm{g} / \mathrm{I}^{34}$. Arsenic contents of $100 \%$ rice beers have not previously been reported. 


\section{Conclusions}

404 We have demonstrated the feasibility of using the Indian black rice Chakhao Poireiton to make 405 beer in a process using $100 \%$ malted rice. This could be of interest as an alternative raw 406 material for the brewing industry in the fastest growing economy in the world, namely India. 407 Black rice beers contained a much higher total polyphenol content (TPC) than white rice beers 408 and were pinkish-orange in colour due to the presence of anthocyanin pigments at low $\mathrm{pH}$. 409 The FAN content of black rice malt worts was low and supplementation with additional 410 nitrogen sources would doubtless be required for commercial brewing. Interestingly, ESR 411 measurements indicated that beers made from 100\% malted rice were unusually oxidatively 412 stable and in future studies it would be interesting to see if this confers enhanced flavour 413 stability through shelf-life. When blended with a barley malt-derived lager beer in various 414 proportions the black rice beer in particular improved the oxidative stability of the resulting 415 blend on a proportionate basis. It is proposed that the black rice beer both lacked pro-oxidant 416 species which are present in barley malt-derived beers and also contains additional anti417 oxidant species (e.g. anthocyanins). Further studies are required to develop understanding of 418 the impacts of adjunct and alternative raw materials usage on beer oxidative stability and to 419 establish whether the noted oxidative stability of $100 \%$ rice beers would actually confer a 420 particularly flavour stable product. 


\section{Acknowledgements}

422 We would like to thank the Research Pilot Brewery (RPB; AB InBev) at Sutton Bonington for 423 use of their Bruker E-scan instrument for ESR spectroscopy measurements.

424 Kamaljit Moirangthem gratefully acknowledges the technical support of members of the 425 International Centre for Brewing Science for their support (as stated): Susan Clegg 426 (Micromalting of rice); Dave Greening (Brewing trials technical support); Emily Fong 427 (fermentation flavour volatiles and VDK analysis); Olayide Oladokun (analysis of 428 polyphenolics) and Arthur Gadon (ICP-MS).

429

430

Notes

431 The authors declare no competing financial interest.

432 


\section{REFERENCES}

1. FAO. (2017) Rice Market Monitor. FAO Food and Agricultural Organization. XX, 1-35.

2. Roy, S., Banerjee, A., Pattanayak, A., and Roy, S.S. (2014) Chakhao (delicious) rice landraces (Oryza sativa L.) of North-east India: collection, conservation and characterization of genetic diversity. Plant Genet. Resour. 12, 264-272. https://doi.org/10.1017/S1479262113000580

3. Wahengbam, R. C. S., Heigrujam, B. S., Wahengbam, N. S., and Nongmaithem, M.S. (2015) An easy and reliable technique for the extraction of genomic DNA from the young leaves of black scented rice (Chakhao). Eur. J. of Exp. Biol. 5, 15-17.

4. Asem, I. D., Imotomba, R. K., Mazumder, P. B., and Laishram, J. M. (2015) Anthocyanin content in the black scented rice (Chakhao): its impact on human health and plant defense. Symbiosis. 66, 47-54. https://doi.org/10.1007/s13199-015-0329-z

5. Hou, D.X. (2003) Potential Mechanisms of Cancer Chemoprevention by Anthocyanins. Curr. Mol. Med. 3, 149-159. https://doi.org/10.2174/1566524033361555

6. Abdel-Aal, E. S. M., Abou, A.A., Gamel, T.H, Huci, P., Young, J.C., and Rabalsk, I. (2008) Fractionation of Blue Wheat Anthocyanin Compounds and Their Contribution to Antioxidant Properties. J. Agric. Food Chem. 56, 11171-11177. https://doi.org/10.1021/jf802168c

7. Kushwaha, U. K. S. (2016) Rice in Black Rice: Research, History and Development (ed. Kushwaha, U.K.S.) pp. 21-47, Springer International Publishing. http://dx.doi.org/10.1007/978-3-319-30153-2_1

8. Reddy, C. K., Kimi, L., and Haripriya, S. (2016) Variety difference in molecular structure, functional properties, phytochemical content and antioxidant capacity of pigmented rice. $J$. Food Meas. Charact. 1-9. doi:10.1007/s11694-016-9344-x

9. Mayer, H., Ceccaroni, D., Marconi, O., Sileoni, V., Perretti, G., and Fantozzi, P. (2016) Development of an all rice malt beer: A gluten free alternative. LWT - Food Sci. Technol. 67, 67-73. https://doi.org/10.1016/j.lwt.2015.11.037

10. Usansa, U., Sompong, N., Wanapu, C., Boonkerd, N., and Teaumroong, N. (2009) The Influences of Steeping Duration and Temperature on the $\alpha$ - and $\beta$-Amylase Activities of Six Thai Rice Malt Cultivars (Oryza sativa L. Indica). J. Inst. Brew. 115, 140-147. https://doi.org/10.1002/j.2050-0416.2009.tb00359.x

11. Ceccaroni, D., Sileonia, V., Marconia, O., De Francesco, G., Lee, E.G., and Perrettia, G. (2019) Specialty rice malt optimization and improvement of rice malt beer aspect and aroma. $L W T$ Food Sci. Technol. 99, 299-305. https://doi.org/10.1016/j.Iwt.2018.09.060

12. Lorenz, K., and D'Appolonia, B. (2009) Cereal sprouts: Composition, nutritive value, food applications. Crit. Rev. Food Sci. Nutr. 13, 353-385. https://doi.org/10.1080/10408398009527295

13. Usansa, U., Burberg, F., Geiger, E., Back, W., Wanapu, C., Arendt, E.K., Kreisz, S., Boonkerd, N., Teaumroong, N., and Zarnkow, M. (2011) Optimization of Malting Conditions for Two Black Rice Varieties, Black Non-Waxy Rice and Black Waxy Rice (Oryza sativa L. Indica). J. Inst. Brew. 117, 39-46. https://doi.org/10.1002/j.2050-0416.2011.tb00441.x

14. Minh, N. P. (2014) Different factors affecting to waxy black rice malt production. Int. J. Multidiscip. Res. Dev. 1, 41-48.

15. Ceppi, E. L. M., and Brenna, O. V. (2010) Brewing with Rice Malt - A Gluten-free Alternative. J. Inst. Brew. 116, 275-279. https://doi.org/10.1002/j.2050-0416.2010.tb00431.x 
16. Oladokun, O., James, S., Cowley, T., Dehrmann, F., Smart, K., Hort, J., and Cook, D. (2017) Perceived bitterness character of beer in relation to hop variety and the impact of hop aroma. J. Food Chem. 230, 215-224. https://doi.org/10.1016/j.foodchem.2017.03.031

17. Sutharut, J., and Sudarat, J. (2012) Total anthocyanin content and antioxidant activity of germinated colored rice. Int. Food Res. J. 19, 215-221. https://doi.org/10.11113/jt.v80.11135

18. Jenkins, D., James, S., Dehrmann, F., Smart, K., and Cook, D. (2018) Impacts of Copper, Iron, and Manganese Metal lons on the EPR Assessment of Beer Oxidative Stability. J. Am. Soc. Brew. Chem. 76, 50-57. https://doi.org/10.1080/03610470.2017.1402585

19. Mayer, H., Marconi, O., Regnicoli, G. F., Perretti, G., and Fantozzi, P. (2014) Production of a Saccharifying Rice Malt for Brewing Using Different Rice Varieties and Malting Parameters. J. Agric. Food Chem. 62, 5369-5377. https://doi.org/10.1021/jf501462a

20. Pode, R. (2016) Potential applications of rice husk ash waste from rice husk biomass power plant. Renew. Sust. Energ. Rev. 53, 1468-1485. https://doi.org/10.1016/j.rser.2015.09.051

21. Essery, R. E., Kirsop, B.H., and Pollock, J.R.A. (2013) Studies in Barley and Malt V. Determination of Husk-Content and Mealiness of Barley. J. Inst. Brew. 62, 150-152. https://doi.org/10.1016/j.rser.2015.09.051

22. Saikia, S., Dutta, H., Saikia, D., and Mahanta, C. L. (2012) Quality characterisation and estimation of phytochemicals content and antioxidant capacity of aromatic pigmented and non-pigmented rice varieties. Food Res. Int. 46, 334-340. https://doi.org/10.1016/j.foodres.2011.12.021

23. Boulton, C., and Quain, D. 2006 The Biochemistry of Fermentation, in Brewing Yeast and Fermentation (eds. Boulton, C. \& Quain, D.) pp. 69-142, Blackwell Science Ltd. https://doi:10.1002/9780470999417.ch3

24. Hiemori, M., Koh, E., and Mitchell, A. E. (2009) Influence of Cooking on Anthocyanins in Black Rice ( Oryza sativaL. japonicavar. SBR). J. Agric. Food Chem. 57, 1908-1914. https://doi.org/10.1021/jf803153

25. Zhao, H., Chen, W., Lu, J., and Zhao, M. (2010) Phenolic profiles and antioxidant activities of commercial beers. J. Food Chem. 119, 1150-1158.

http://dx.doi.org/10.1016/j.foodchem.2009.08.028

26. Branyik, T., Vicente, A. A., Dostalek, P., and Teixeira, J. A. (2008) A Review of Flavour Formation in Continuous Beer Fermentations. J. Inst. Brew. 114, 3-13. https://doi.org/10.1002/j.2050-0416.2008.tb00299.x

27. Bamforth, C.W., and Kanauchi, M. (2004) Enzymology of Vicinal Diketone Reduction in Brewer's Yeast. J. Inst. Brew. 110, 83-93. https://doi.org/10.1002/j.20500416.2004.tb00187.x

28. Willaert, R. (2006) The Beer Brewing Process: Wort Production and Beer Fermentation. Handbook of Food Products Manufacturing. 443-506 (John Wiley \& Sons, Inc., doi:10.1002/9780470113554.ch20

29. Han, H., Kim, J., Choi, E., Ahn, H., and Kim, W. J. (2016) Characteristics of beer produced from Korean six-row barley with the addition of adjuncts. J. Inst. Brew. 122, 500-507. https://doi.org/10.1002/jib.350

30. Fardet, A., Rock, E., and Rémésy, C. (2008) Is the in vitro antioxidant potential of whole-grain cereals and cereal products well reflected in vivo? J. Cereal Science. 48, 258-276. https://doi.org/10.1016/j.jcs.2008.01.002 
31. Teklić, T., Lončarić, Z., Kovačević, V., and Singh, B. R. (2013) Metallic trace elements in cereal grain - a review: how much metal do we eat? Food Energy Secur. 2, 81-95. https://doi.org/10.1002/fes3.24

32. Donadini, G., Spalla, S., and Beone, G. M. (2008) Arsenic, Cadmium and Lead in Beers from the Italian Market. J. Inst. Brew. 114, 283-288. https://doi.org/10.1002/j.20500416.2008.tb00770.x

33. Wyrzykowska, B., Szymczyk, K., Ichichashi, H., Falandysz, J., Skwarzec, B., and Yamasakl, S. (2001) Application of ICP Sector Field MS and Principal Component Analysis for Studying Interdependences among 23 Trace Elements in Polish Beers. J. Agric. Food Chem. 49, 34253431. https://doi.org/10.1021/jf010184g

34. Mahmood, N., Petraco, N., and He, Y. (2011) Elemental fingerprint profile of beer samples constructed using 14 elements determined by inductively coupled plasma-mass spectrometry (ICP-MS): multivariation analysis and potential application to forensic sample comparison. Anal Bioanal Chem. 402, 861-869. https://doi.org/10.1007/s00216-011-5452-y 
Table 1. Steeping and germination conditions used for malting of rice samples in the study.

\begin{tabular}{lcc}
\hline Cycle & $\begin{array}{c}\text { Duration } \\
\text { (h) }\end{array}$ & Temp. $\left({ }^{\circ} \mathbf{C}\right)$ \\
\hline Steep Cycle 1 (wet) & 6.00 & 30 \\
Steep transfer time (14 min per wet cycle) & 0.23 & 30 \\
Steep Cycle 1 (dry) & 3.00 & 30 \\
Steep Cycle 2 (wet) & 6.00 & 30 \\
Steep transfer time (14 min per wet cycle) & 0.23 & 30 \\
Steep Cycle 2 (dry) & 3.00 & 30 \\
Steep Cycle 3 (wet) & 6.00 & 30 \\
Steep transfer time (14 min per wet cycle) & 0.23 & 30 \\
Germination Cycle 1 & 24.00 & 30 \\
Germination Cycle 2 & 24.00 & 30 \\
\hline Total time & 72.69 &
\end{tabular}


Table 2. Black and white rice wort and finished beer analytical parameters.

\begin{tabular}{|c|c|c|c|c|c|c|c|c|c|c|}
\hline & \multicolumn{6}{|c|}{ Apparent } & \multicolumn{4}{|c|}{ Hunter Lab colour } \\
\hline & $\mathrm{pH}$ & $\begin{array}{l}\text { Specific } \\
\text { gravity }\end{array}$ & $\begin{array}{c}\% \\
A B V\end{array}$ & $\begin{array}{c}\text { Fermentabilty } \\
\text { (\%) }\end{array}$ & $\begin{array}{c}\text { FAN } \\
(\mathrm{mg} / \mathrm{mL})\end{array}$ & $\begin{array}{l}\text { Anthocyanins } \\
(\mathrm{mg} / \mathrm{L})\end{array}$ & $\begin{array}{l}\text { EBC } \\
\text { colour }\end{array}$ & $L^{*}$ & $a^{*}$ & $b^{*}$ \\
\hline $\begin{array}{l}\text { Black rice } \\
\text { wort }\end{array}$ & $5.40 \pm 0.20$ & $\begin{array}{c}1.0367 \\
\pm 0.0001\end{array}$ & - & 69.5 & $\begin{array}{r}83.5 \\
\pm 13.4\end{array}$ & $\begin{array}{l}4.93 \\
\pm 1.8\end{array}$ & $\begin{array}{c}13.58 \\
\pm 1.2\end{array}$ & $\begin{array}{c}29.98 \\
\pm 1.3\end{array}$ & $\begin{array}{r}11.67 \\
\pm 1.1\end{array}$ & $\begin{array}{l}14.71 \\
\pm 0.09\end{array}$ \\
\hline $\begin{array}{l}\text { White rice } \\
\text { wort }\end{array}$ & $5.36 \pm 0.06$ & $\begin{array}{l}1.03705 \\
\pm 0.0007\end{array}$ & - & 67.3 & $\begin{array}{c}137 \\
\pm 18.4\end{array}$ & 0 & $\begin{array}{c}5.3 \\
\pm 0.5\end{array}$ & $\begin{array}{c}43.94 \\
\pm 0.6\end{array}$ & $\begin{array}{l}-1.18 \\
\pm 0.03\end{array}$ & $\begin{array}{c}9.50 \pm \\
0.1\end{array}$ \\
\hline $\begin{array}{l}\text { Black rice } \\
\text { beer }\end{array}$ & $3.65 \pm 0.06$ & $\begin{array}{l}1.0112 \\
\pm 0.004\end{array}$ & $\begin{array}{c}3.28 \\
\pm 0.07\end{array}$ & - & $\begin{array}{c}28 \\
\pm 2.8\end{array}$ & $\begin{array}{l}2.84 \\
\pm 0.8\end{array}$ & $\begin{array}{l}8.26 \\
\pm 2.2\end{array}$ & $\begin{array}{c}35.68 \\
\pm 1.9\end{array}$ & $\begin{array}{l}6.37 \\
\pm 1.8\end{array}$ & $\begin{array}{c}12.99 \\
\pm 1.0\end{array}$ \\
\hline $\begin{array}{l}\text { White rice } \\
\text { beer }\end{array}$ & $3.80 \pm 0.08$ & $1.0121 \pm 0$ & $\begin{array}{c}3.19 \\
\pm 0.13\end{array}$ & - & $\begin{array}{l}15 \\
\pm 0\end{array}$ & 0 & $\begin{array}{l}3.41 \\
\pm 1.2\end{array}$ & $\begin{array}{c}44.75 \\
\pm 0.7\end{array}$ & $\begin{array}{l}-1.22 \\
\pm 0.2\end{array}$ & $\begin{array}{r}7.49 \\
\pm 1.1\end{array}$ \\
\hline
\end{tabular}

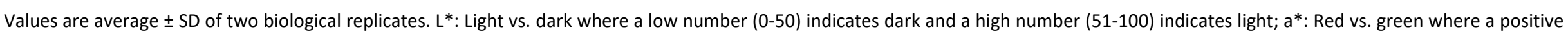
number indicates red and a negative number indicates green; $b^{*}$ : Yellow vs. blue where a positive number indicates yellow and a negative number indicates blue. 
Table 3. Phenolic compound concentrations ( $\mathrm{mg} / \mathrm{L}$ ) in rice worts and beers (by HPLC and ASBC Beer-35)

\begin{tabular}{|c|c|c|c|c|c|c|c|c|c|c|c|c|}
\hline & TPC & HMF & $\begin{array}{c}\text { Protocatechuic } \\
\text { acid }\end{array}$ & Tyrosol & 4-HBA & $\begin{array}{c}\text { Caffeic } \\
\text { acid } \\
(\mathrm{mg} / \mathrm{L})\end{array}$ & $\begin{array}{l}\text { Vanillic } \\
\text { acid }\end{array}$ & $\begin{array}{c}\text { Homo- } \\
\text { vanillic acid }\end{array}$ & $\begin{array}{c}\text { 4-Hydroxy } \\
\text { benzaldehyde }\end{array}$ & $\begin{array}{l}\text { p-coumaric } \\
\text { acid }\end{array}$ & $\begin{array}{l}\text { Ferulic } \\
\text { acid }\end{array}$ & $\begin{array}{l}\text { Indole-3- } \\
\text { acetic acid }\end{array}$ \\
\hline Black wort & $\begin{array}{c}200.7 \\
\pm 26.4\end{array}$ & $\begin{array}{l}0.28 \\
\pm 0.0\end{array}$ & $\begin{array}{l}6.09 \\
\pm 0.03\end{array}$ & 0 & 0 & $\begin{array}{l}0.04 \\
\pm 0.0\end{array}$ & $\begin{array}{l}3.37 \\
\pm 0.0\end{array}$ & $\begin{array}{l}0.12 \\
\pm 0.02\end{array}$ & $\begin{array}{l}0.08 \\
\pm 0.02\end{array}$ & $\begin{array}{l}0.62 \\
\pm 0.02\end{array}$ & $\begin{array}{l}1.46 \\
\pm 0.02\end{array}$ & 0 \\
\hline Black beer & $\begin{array}{c}177.12 \\
\pm 0.0\end{array}$ & $\begin{array}{l}0.22 \\
\pm 0.0\end{array}$ & $\begin{array}{l}7.43 \\
\pm 0.01\end{array}$ & $\begin{array}{c}10.64 \\
\pm 0.03\end{array}$ & 0 & $\begin{array}{l}0.03 \\
\pm 0.0\end{array}$ & $\begin{array}{l}3.06 \\
\pm 0.01\end{array}$ & $\begin{array}{l}0.17 \\
\pm 0.02\end{array}$ & $\begin{array}{l}0.04 \\
\pm 0.01\end{array}$ & $\begin{array}{l}0.50 \\
\pm 0.0\end{array}$ & $\begin{array}{l}1.37 \\
\pm 0.0\end{array}$ & $\begin{array}{l}2.14 \\
\pm 0.01\end{array}$ \\
\hline White wort & $\begin{array}{c}58.63 \\
\pm 6.4\end{array}$ & $\begin{array}{c}0.22 \\
\pm 0.01\end{array}$ & 0 & 0 & 0 & 0 & $\begin{array}{l}0.29 \\
\pm 0.01\end{array}$ & $\begin{array}{l}0.15 \\
\pm 0.0\end{array}$ & $\begin{array}{l}0.08 \\
\pm 0.01\end{array}$ & $\begin{array}{l}0.82 \\
\pm 0.0\end{array}$ & $\begin{array}{l}1.06 \\
\pm 0.03\end{array}$ & 0 \\
\hline White beer & $\begin{array}{c}43.77 \\
\pm 0.4\end{array}$ & $\begin{array}{c}0.18 \\
\pm 0.02\end{array}$ & 0 & $\begin{array}{l}24.68 \\
\pm 0.05\end{array}$ & $\begin{array}{l}0.33 \\
\pm 0.02\end{array}$ & 0 & $\begin{array}{l}0.52 \\
\pm 0.01\end{array}$ & $\begin{array}{l}0.25 \\
\pm 0.03\end{array}$ & $\begin{array}{l}0.31 \\
\pm 0.02\end{array}$ & $\begin{array}{l}0.99 \\
\pm 0.01\end{array}$ & $\begin{array}{l}1.23 \\
\pm 0.03\end{array}$ & $\begin{array}{l}2.09 \\
\pm 0.03\end{array}$ \\
\hline
\end{tabular}

Values are average \pm SD of two biological replicates.

TPC: Total phenolic content; HMF: Hydroxymethylfurfural; HBA: 4-Hydroxybenzoic Acid. 
Table 4. Fermentation volatile concentrations in rice beers.

\begin{tabular}{lccc} 
& $\begin{array}{c}\text { Black rice beer } \\
(\mathrm{mg} / \mathrm{L})\end{array}$ & $\begin{array}{c}\text { White rice beer } \\
(\mathrm{mg} / \mathrm{L})\end{array}$ & $\begin{array}{c}\text { Literature value for Barley } \\
\text { malt bottom-fermented beer } \\
(\mathrm{mg} / \mathrm{L})\end{array}$ \\
\hline $\begin{array}{l}\text { VDK } \\
\text { Butanedione }\end{array}$ & $0.34 \pm 0.113$ & $0.055 \pm 0.021$ & \\
Pentanedione & $0.03 \pm 0.014$ & $0.005 \pm 0.007$ & $10-40$ \\
Esters & $7.0 \pm 0.14$ & $11.5 \pm 3.0$ & \\
Ethyl acetate & $0.125 \pm 0.007$ & $0.105 \pm 0.007$ & $0.05-0.15$ \\
Isobutyl acetate & $0.06 \pm 0.014$ & $0.06 \pm 0$ & $0.5-3$ \\
Ethyl butyrate & $0.675 \pm 0.078$ & $0.465 \pm 0.021$ & $0.05-0.3$ \\
Isoamyl acetate & $0.025 \pm 0.035$ & $\mathrm{ND}$ & $0.1-0.5$ \\
Ethyl hexanoate & $0.05 \pm 0.014$ & \\
Ethyl octanoate & $0.07 \pm 0.042$ & & $5-20$ \\
Higher alcohols & $13.8 \pm 0.56$ & $52.9 \pm 1.4$ & $5-20$ \\
$\mathrm{n}$-propanol & $62.5 \pm 4.1$ & $83.0 \pm 16.0$ & $30-70$ \\
isobutanol & $72.1 \pm 5.9$ & & \\
Isoamyl alcohol & & & \\
\hline
\end{tabular}

Data are the mean of two biological replicates $\pm S D ; N D=$ not detected. 
Table 5. Elemental composition of beers brewed from $100 \%$ malted black or white rice cultivars as compared with a control lager beer brewed from $100 \%$ barley malt.

\begin{tabular}{|c|c|c|c|c|c|c|c|c|c|c|c|c|c|c|}
\hline $\mathrm{mg} / \mathrm{L}$ & B & $\mathrm{Na}$ & $\mathrm{Mg}$ & $P$ & $S$ & K & $\mathrm{Ca}$ & $\mathrm{Ti}$ & & & & & & \\
\hline Black & 0.180 & 11.58 & 99.68 & 596.95 & 20.69 & 270.59 & 40.36 & $\begin{array}{ll}6 & 0.009\end{array}$ & & & & & & \\
\hline White & 0.163 & 12.20 & 94.52 & 470.62 & 24.46 & 221.88 & $32.4 \mathrm{c}$ & 90.007 & & & & & & \\
\hline Control & 0.155 & 10.05 & 55.79 & 466.61 & 68.44 & 601.08 & 22.71 & 10.007 & & & & & & \\
\hline$\mu \mathrm{g} / \mathrm{L}$ & $\mathrm{Li}$ & & $\mathrm{Be}$ & $\mathrm{Al}$ & V & $\mathrm{Cr}$ & & $\mathrm{Mn}$ & $\mathrm{Fe}$ & Co & $\mathrm{Ni}$ & $\mathrm{Cu}$ & $\mathrm{Zn}$ & \\
\hline Black & 2.41 & & .040 & 11.69 & 0.023 & 1.12 & & 3421.6 & 5.71 & 0.083 & 4.767 & 18.72 & 16.24 & \\
\hline White & 2.73 & & .048 & 9.44 & 0.078 & 1.80 & & 1858.6 & 14.27 & 0.096 & 7.41 & 35.57 & 8.98 & \\
\hline Control & 2.03 & & .078 & 14.41 & 0.581 & 8.23 & & 177.8 & 99.70 & 0.120 & 5.14 & 209.99 & 25.61 & \\
\hline$\mu \mathrm{g} / \mathrm{L}$ & As & & $\mathrm{Se}$ & $\mathrm{Rb}$ & $\mathrm{Sr}$ & Mo & & $\mathrm{Ag}$ & $\mathrm{Cd}$ & Cs & $\mathrm{Ba}$ & $\mathrm{TI}$ & $\mathrm{Pb}$ & U \\
\hline Black & 14.87 & & 1.89 & 2153.39 & 119.99 & 0.41 & & 0.003 & 0.019 & 0.627 & 51.85 & 0.009 & 0.718 & 0.003 \\
\hline White & 27.96 & & 0.71 & 190.35 & 97.88 & 13.52 & & 0.003 & 0.072 & 0.115 & 21.51 & 0.008 & 1.190 & 0.007 \\
\hline Control & 0.50 & & 0.56 & 135.49 & 78.78 & 2.77 & & 0.002 & 0.027 & 0.164 & 14.04 & 0.031 & 3.154 & 0.005 \\
\hline
\end{tabular}

Values are the average of 8 replicate determinations. 


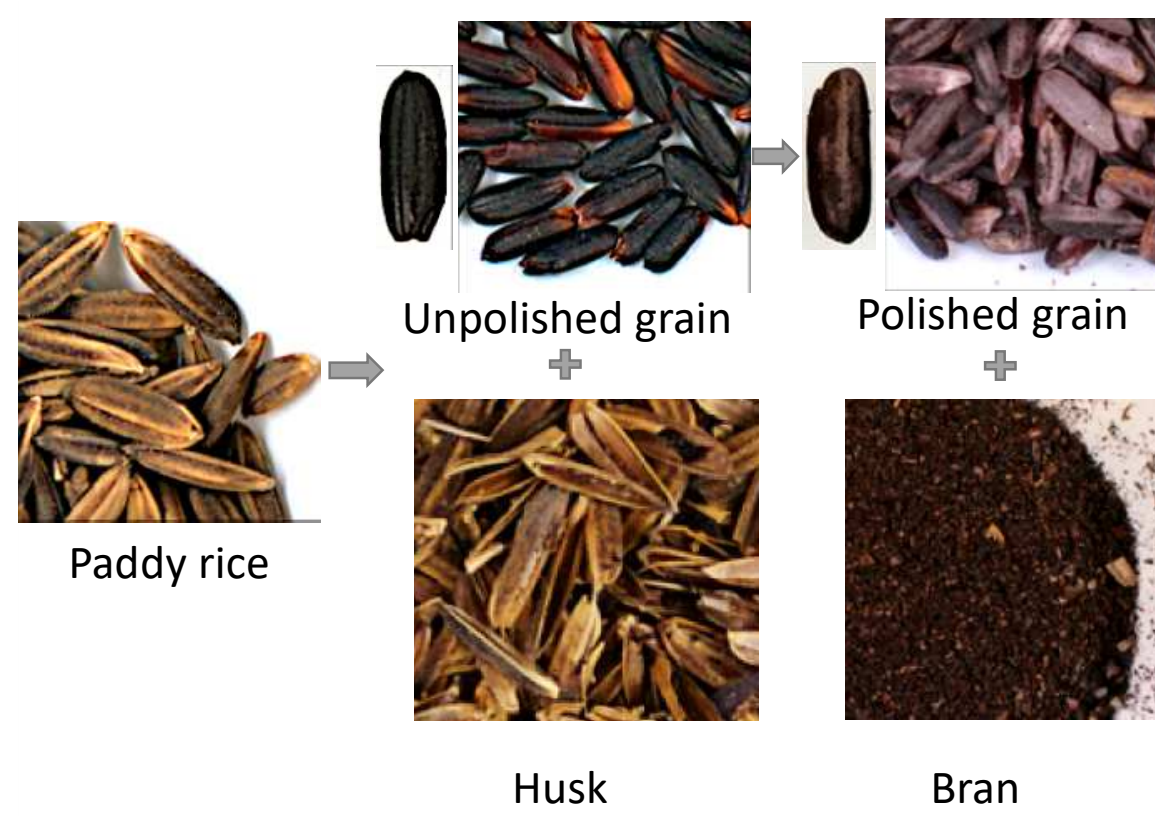

Figure 1. Different fractions of black paddy rice (Chakhao Poireiton) as it undergoes industrial milling. 


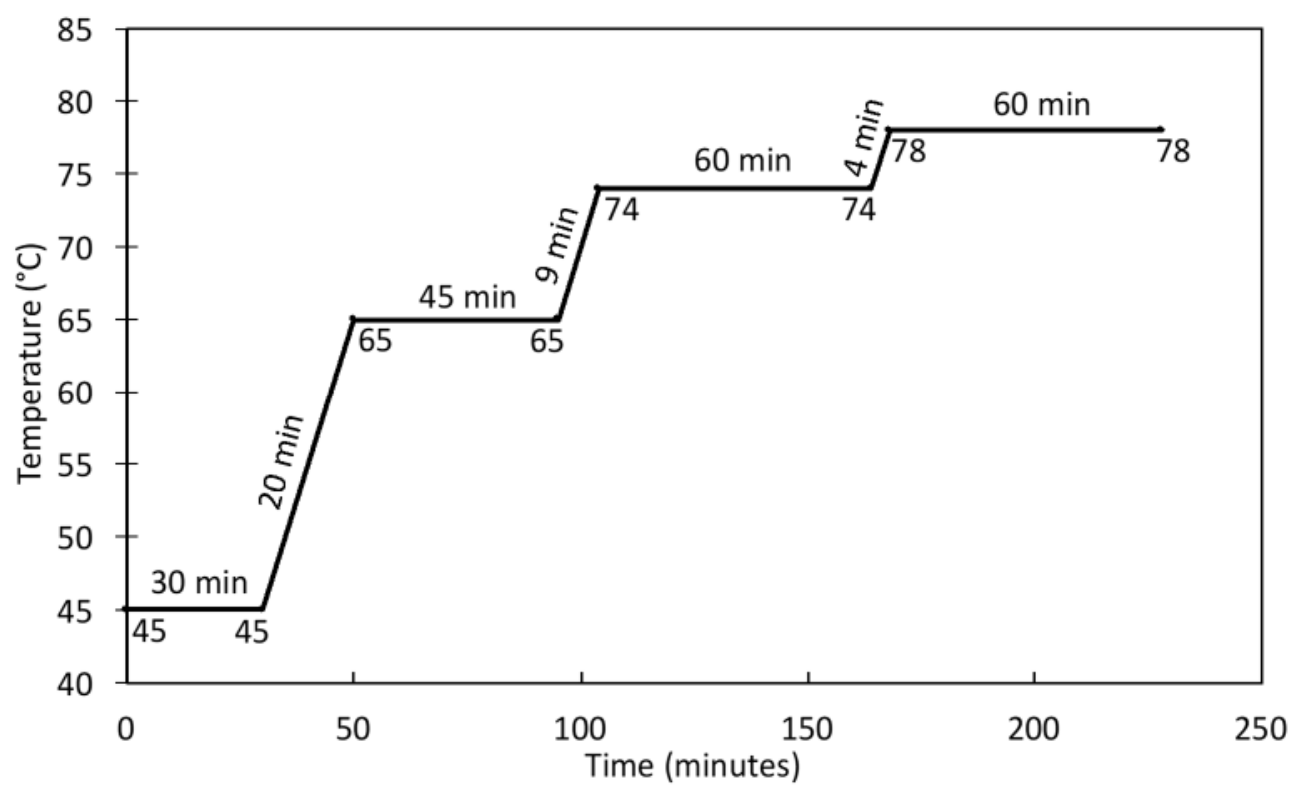

Figure 2. Time-temperature mash schedule used for brewing beers with $100 \%$ malted rice 

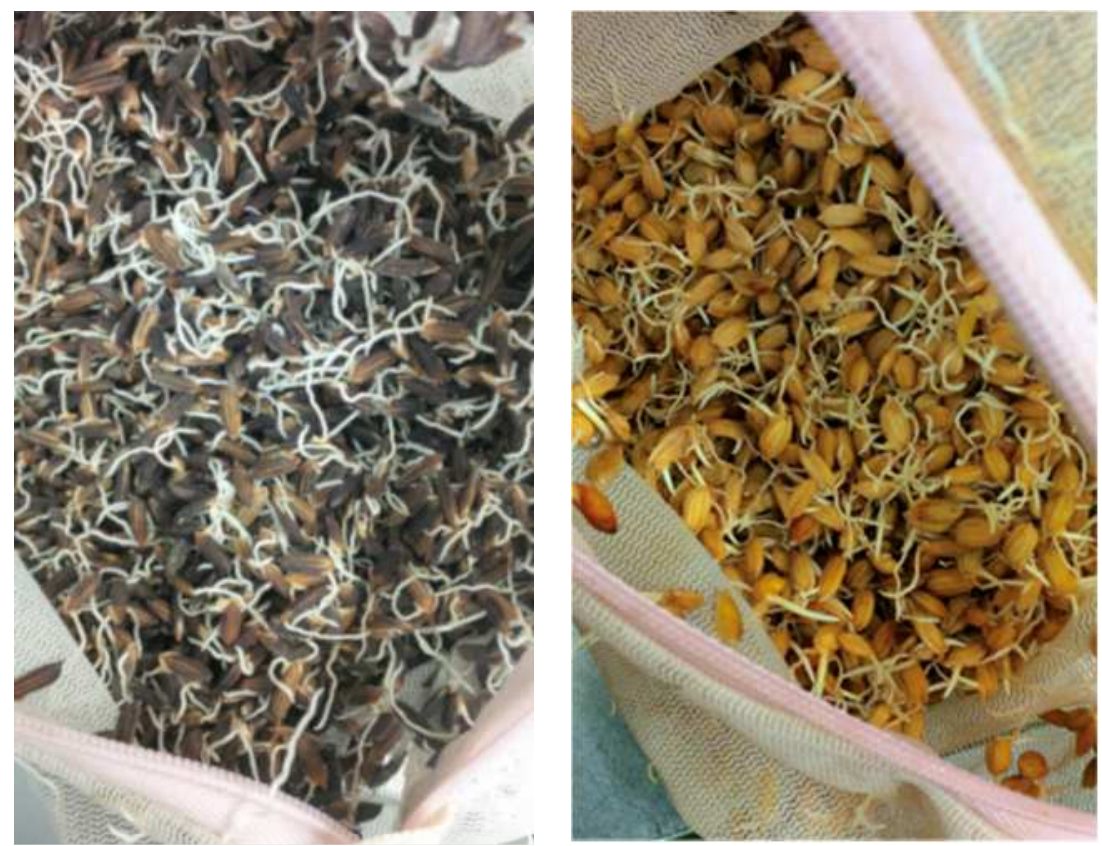

Figure 3. Germinated paddy black (left) and white rice (right) 

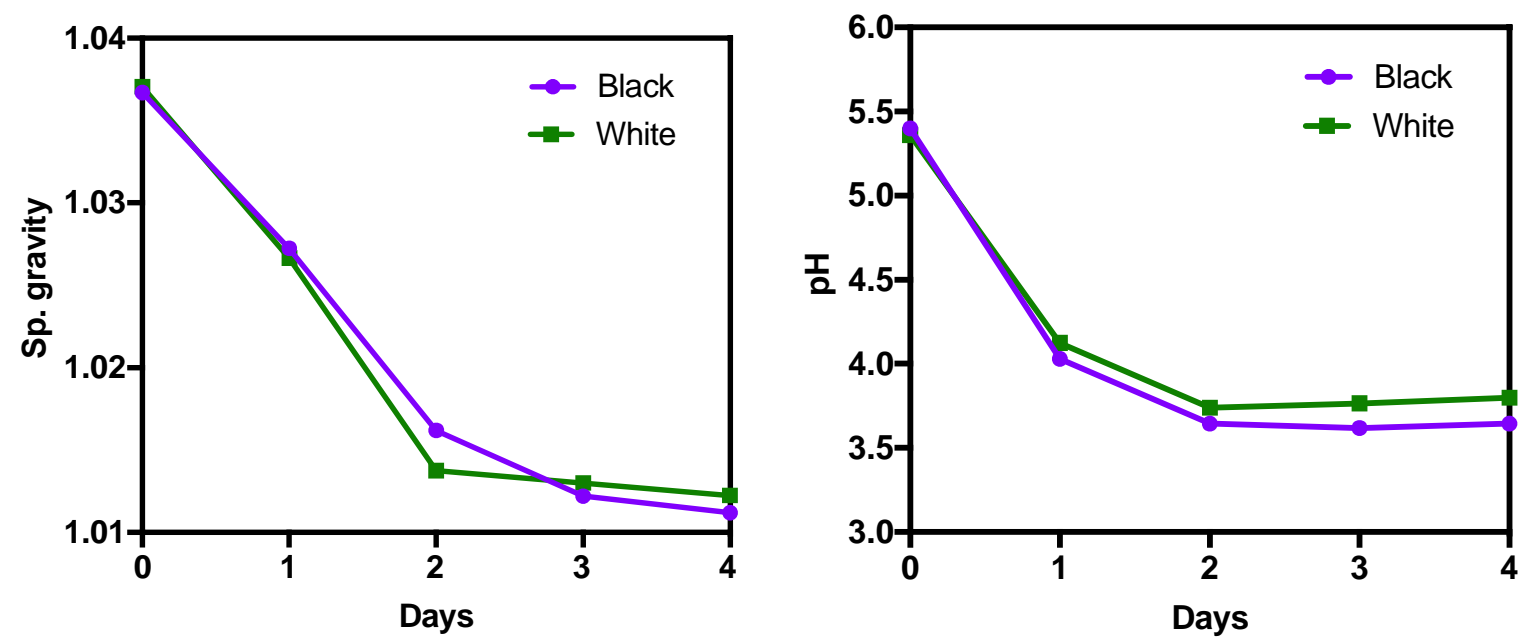

Figure 4. Changes in specific gravity and $\mathrm{pH}$ through fermentation of black and white rice worts 


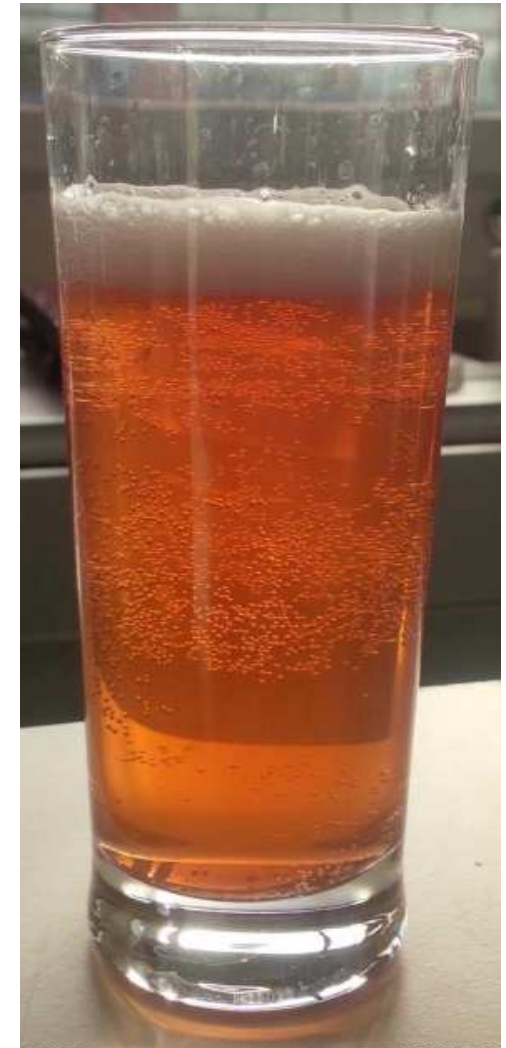

Black rice beer

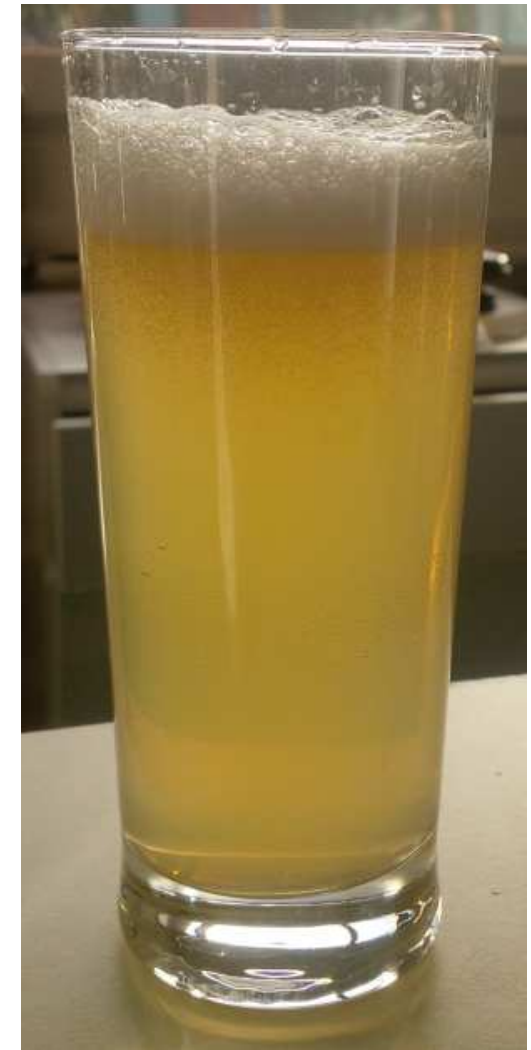

White rice beer

Figure 5. Black and white rice beers photographed after 21 days of bottle conditioning. 


\section{A. Rice beers post-fermentation}

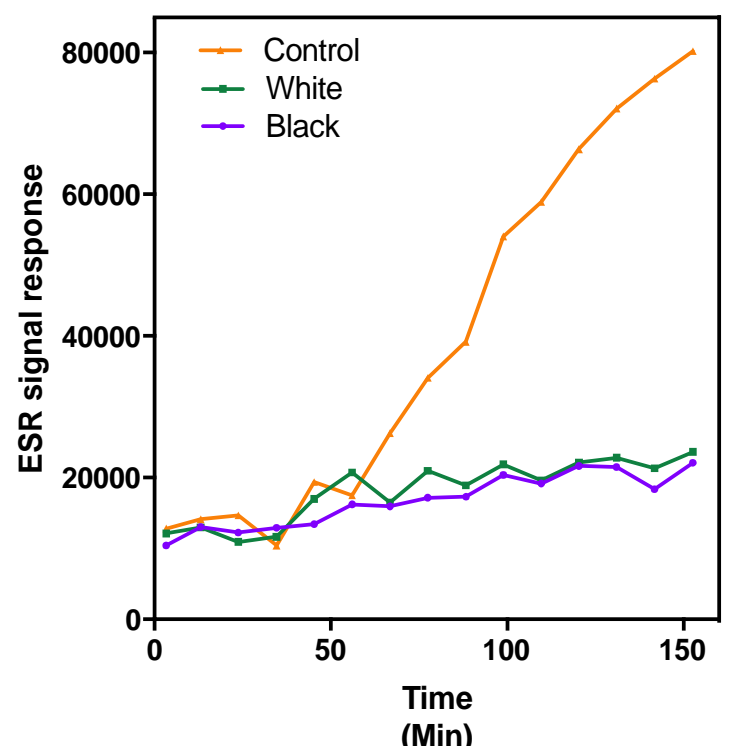

C. Blends of black rice beer with commercial lager

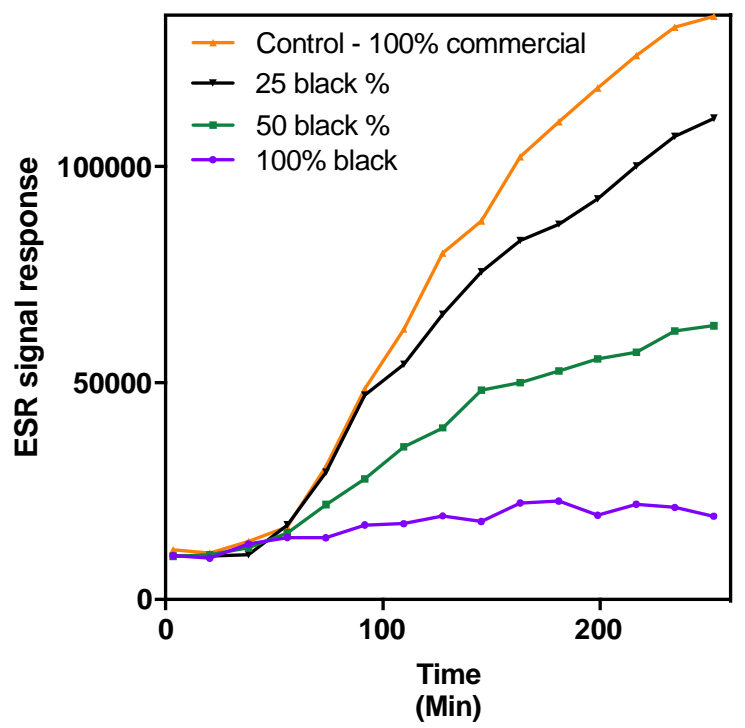

B. Rice beers post bottle conditioning

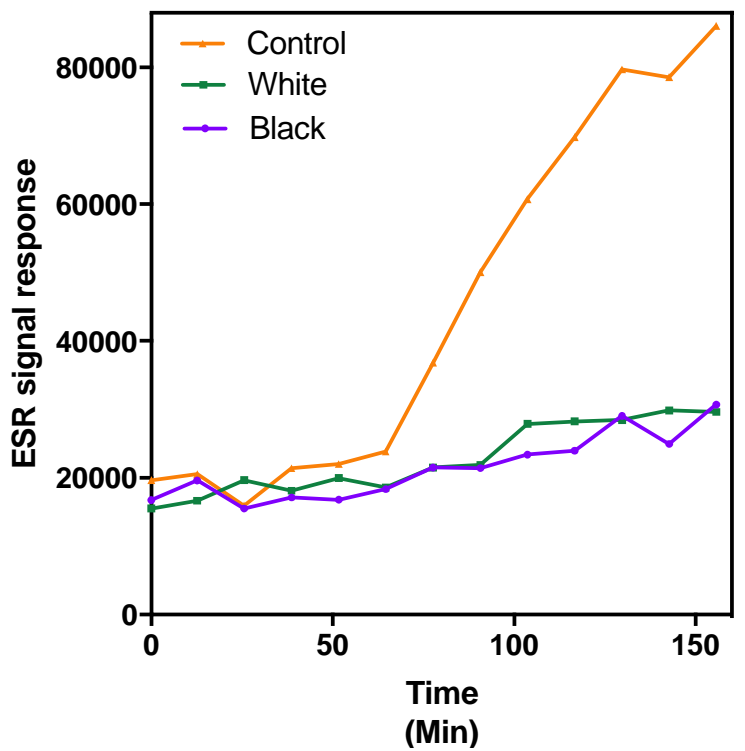

D. Blends of white rice beer with commercial lager

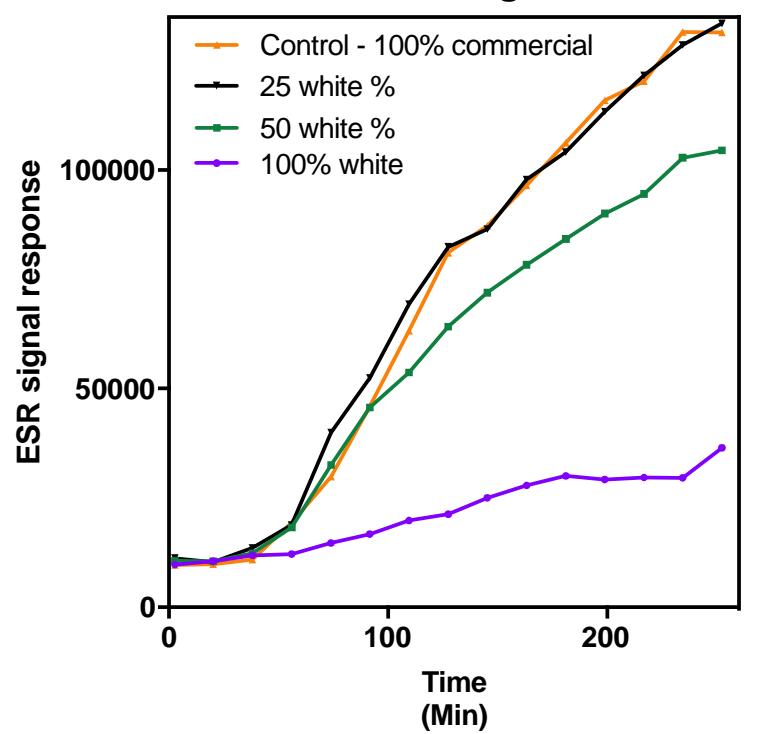

Figure 6. Oxidative stability of rice beers, and blends of rice beers with a commercial lager assessed using ESR spectroscopy

Control - commercial lager beer brewed using 100\% barley malt; A - ESR response of back and white rice beers after fermentation; B - ESR response of back and white rice beer after 21 days of bottling (mature); C,D - ESR response of mature black and white rice beer respectively, mixed at different proportions with the control lager beer; Data are average of two biological replicates. 
A.

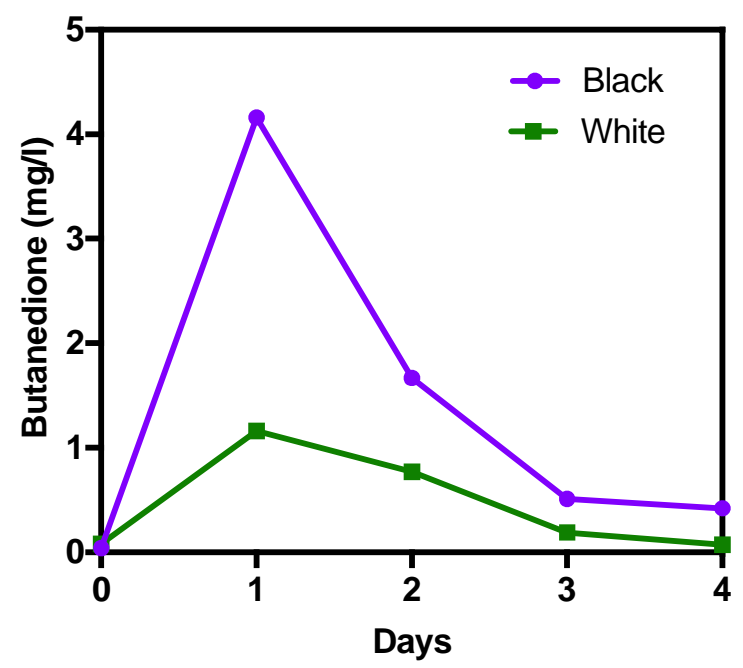

B.

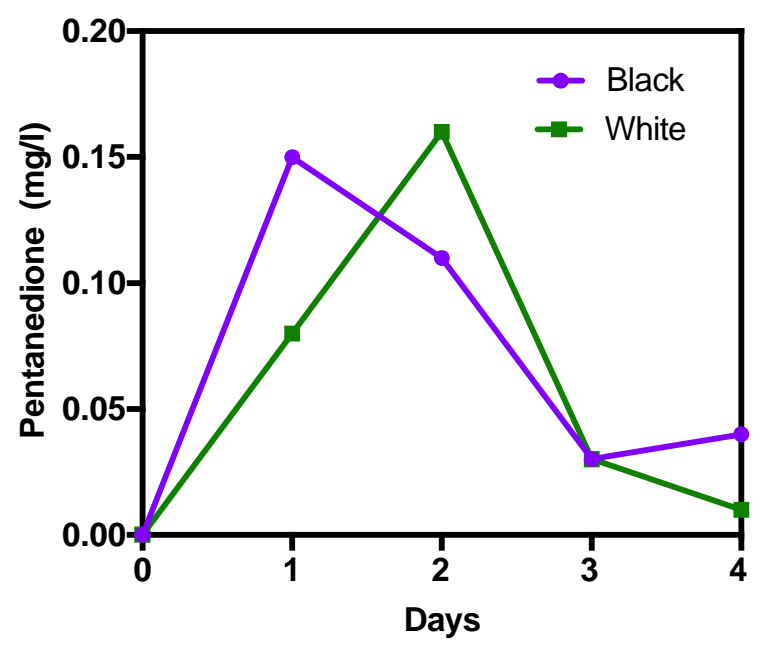

Figure 7. Example VDK profiles through fermentation of malted black and white rice worts. A. butanedione and B. pentanedione. 